\title{
Analysis of the glucokinase gene in Iranian families with maturity onset diabetes of the young
}

\author{
Meisam Javadi ${ }^{1}$, Houshang Rafatpanah ${ }^{2}$, Seyed Morteza Taghavi ${ }^{3}$, Jalil Tavakolafshari ${ }^{2}$, \\ Rashin Ganjali ${ }^{4}$, Narges Valizadeh ${ }^{4}$, Seyedeh Seddigheh Fatemi ${ }^{5^{*}}$ \\ ${ }^{1}$ Mashhad University of Medical Sciences, Mashhad, Iran \\ ${ }^{2}$ Immunogenetics Department, Immunology Research Center, Bu-Ali Research Center, Mashhad University of Medical Sciences, \\ Mashhad, Iran \\ ${ }^{3}$ Internal Medicine Department, Ghaem Hospital and Endocrine Research Center, Mashhad University of Medical Sciences, Mashhad, \\ Iran \\ ${ }^{4} \mathrm{Bu}$-Ali Research Center, Mashhad University of Medical Sciences, Mashhad, Iran \\ ${ }^{5}$ Immunogenetics Department, Immunology Research Center, Bu-Ali Research Center, Mashhad University of Medical Sciences, \\ Mashhad, Iran; ${ }^{*}$ Corresponding Author: shayesteh78@yahoo.com
}

Received 3 June 2013; revised 2 July 2013; accepted 10 July 2013

Copyright (C) 2013 Meisam Javadi et al. This is an open access article distributed under the Creative Commons Attribution License, which permits unrestricted use, distribution, and reproduction in any medium, provided the original work is properly cited.

\section{ABSTRACT}

Non insulin dependent diabetes mellitus (NIDDM) as a most common form of diabetes is a major public health problem; there is a subgroup of NIDDM patients who develop the disease at an early age and show a dominant mode of inheritance. This type is nominates Maturity onset diabetes of the young (MODY). The prevalence of MODY is difficult to access, and patients with MODY genes mutations are often identified during routine screening for other purposes. MODY2 was linked to glucokinase gene (GCK) mutations, and accounted for $8 \%$ to $56 \%$ of MODY, with the highest prevalence found in the southern Europe. The aim of this study was to examine the prevalence and nature of mutations in GCK gene in Iranian paients. We have screened GCK mutations by polymerase chain reaction (PCR); single stranded conformation polymorphism (SSCP) technique in 12 Iranian families with clinical diagnosis of MODY, included 30 patients (8 males and 22 females) and their 21 family members. PCR products with abnormal mobility in denaturing gradient gel electrophoresis (DGGE) were directly sequenced. We identified 6 novel mutations in GCK gene in Iranian families (corresponding to $36.6 \%$ prevalence). Our findings and the last study on MODY1 highlight that in addition to GCK, other MODY genes such as MODY3 and MODYX may play a significant role in diabetes characterized by monogenic auto- somal dominant transmission. There is an important point that the genetic recognation can be used to pre-symptomatically identify family members at risk for developing MODY.

Keywords: Maturity Onset Diabetes of the Young 2 (MODY2); Glucokinase (GCK); Mutation; SSCP; PCR

\section{INTRODUCTION}

Maturity onset diabetes of the young (MODY) is an autosomal dominant form of non insulin dependent diabetes mellitus (NIDDM) which is characterized by an early age at onset (usually before 25 years), with at least one family member with diabetes and a primary defect in beta cell function. Except for these features, the clinical characteristics of MODY patients are similar to the patients with the more common late onset form of NIDDM [1]. The maturity onset diabetes of the young (MODY), is caused by mutations in the six known genes encoding the hepatocyte nuclear factor- $4 \alpha(\mathrm{HNF}-4 \alpha)$, glucokinase (GCK), hepatocyte nuclear factor- $1 \alpha$ (HNF-1 $\alpha$ ), insulin promoter factor-1(IPF-1), hepatocyte nuclear factor- $1 \beta$ (HNF-1 $\beta$ ) and NeuroD1 respectively [2]. The diagnosis of MODY is very important in children and adolescent diabetic patients $[3,4]$. Although the true relative prevalence of six distinct MODY subtypes is unknown and varies substantially in studies in various populations [510], mutations in the genes encoding HNF1 $\alpha$ and GCK are the most prevalent. Mutations in GCK (MODY2) account for $7 \%-41 \%[8,9]$, whereas mutations in TCF1 
(MODY3) may account for $11 \%-63 \%$ of mutations in subjects with clinically diagnosed MODY. Mutations in HNF4 $\alpha$ (MODY1) are less frequent and may account for $2 \%-5 \%$ of subjects with MODY [7,10]. Only 26 families worldwide have been diagnosed with MODY1 [11]. The prevalence of MODY patients with mutations in TCF2 (MODY5) is unknown, and although MODY5 has been considered very rare, it may comprise up to approximately $1 \%$. Mutations in IPF1 and NEUROD1 are rare and have been identified in single families. Interestingly, unknown MODY genes, known as MODYX, may be responsible for up to $79 \%$ of cases of MODY depending on sampling and the stringency of inclusion criteria [8]. This finding suggests that additional MODY genes are likely to exist. Each genetic sub group is associated with a distinct phenotype [12]. Despite the molecular genetic heterogeneity, the overall mechanisms leading to MODY are typically defective insulin secretion and/or reduced pancreatic beta cell mass due to impaired transcriptional regulation of cell development and function [13].

Mutations in the glucokinase gene may be the most common cause of type 2 diabetes identified up to this time $(8 \%$ to $63 \%)$ [10]. More than 100 different mutations have been linked to a subtype of type 2 diabetes called maturity onset diabetes of the young type 2 (MODY2) [14-21]. This form of type 2 diabetes is characterized by mild and stable hyperglycemia from begin of birth results a defect in glucose induced insulin secretion rather than insulin action [22-24]. Most cases of MODY2 are treated only by diet and they rarely suffer diabetic complications. Glucokinase plays a key role in the regulation of glucose homeostasis. This enzyme is expressed in the pancreatic beta cells and liver, and catalyses the formation of glucose 6 phosphate and may be involved in the regulation of insulin secretion and integration of hepatic intermediary metabolism [16]. So, in the hepatocyte, the phosphorylation of glucose by glucokinase facilitates the uptake and metabolism of glucose by maintaining a gradient for glucose transport into these cells thereby regulating hepatic glucose disposal [14]. Studies of MODY caused by mutations in GCK have shown that decreased expression (insufficiency) of functional GCK causes hyperglycemia due to reduced glucose sensing [18,25,26].

At first, we screened our patients with clinical features of MODY, for mutations in HNF4 $\alpha$ gene and we identified the novel mutation in this gene in $8 / 30(26.6 \%)$ of patients and $3 / 21(14.2 \%)$ of their relatives [27]. These results are different from other populations. So, we should examine our patients to distinguish the prevalence of the mutations between other 5 MODY genes and MODYX. In this study, we have searched for mutations in the glucokinase gene in 30 patients from 12 Iranian families with clinically MODY diagnosis.

\section{MATERIAL AND METHODS}

We selected 30 subjects ( 8 males and 22 females) with clinical features of MODY and their family members (21 persons) participated too. These subjects were previously diagnosed to suffer from diabetes mellitus or impaired fasting glucose (IFG) and all had a family history of diabetes mellitus or another form of hyperglycemia (gestational diabetes mellitus or impaired glucose tolerance) in at least two consecutive generations. The patients were recruited from pediatric endocrinologists and from outpatient clinics for adults from whole academic endocrinology departments of Mashhad (Eastern Center of Iran) during 2006 to 2010. The study protocol was approved by Mashhad University of Medical Sciences Ethical Committees. Informed consent was obtained from all study participants.

Family history and clinical, metabolic and genetic data were collected in 12 Iranian families included 30 MODY patients as well as their relatives. Fifty unrelated normoglycemic subjects were included in the study as controls.

All participants had fasting blood samples taken for measurements of plasma glucose and glycosylated hemoglobin (HbA1C). Participants with no known history of diabetes had an additional standard 75-g oral glucose tolerance test performed. In those patients treated with insulin, its administration was started after a documented failure of diet and sulfonylurea drugs. Failure is defined as sustained fasting glucose greater than $140 \mathrm{mg} / \mathrm{dl}$, ketosis, or abnormalities in growth rate. Diagnosis of chronic diabetes complications was based on standard studies (serum lipid profile, blood pressure, microalbuminuria, and eye fundoscopy). The existence of chronic complications in affected relatives was assessed from medical files.

Genomic DNA was extracted from peripheral white blood cells or lymphocyte cell line using standard methods. The gene encoding the enzyme glucokinase in human spans a region of more than 20 kilobases $(\mathrm{kb})$ on chromosome 7, and consists of 12 exons. All exons of GCK gene were amplified using PCR and were scanned for mutations by single strand conformational polymorphism (SSCP) technique. PCR products corresponding to abnormal electrophoretic patterns were purified and analyzed by direct sequencing in both directions using ABI PRISM Dye Primer Cycle Sequencing Kit with Amplitaq DNA Polymerase FS to characterize nucleotide change and results were analyzed with ABI Sequence Navigator software. The published primers were used (Table 1). Family members were screened for the mutation similar to the patients. Absence of the newly described variants was checked in the 50 control subjects using the same 
Table 1. Sequences of primer pairs for PCR-SSCP analysis of human GCK.

\begin{tabular}{|c|c|c|c|}
\hline Exon & Upstream primer & Downstream primer & Size, bp \\
\hline 1a & 5'-TCCACTTCAGAAGCCTACTG & 5'-TCAGATTCTGAGGCTCAAAC & 195 \\
\hline $1 b$ & 5'-AGCAGGCAGGAGCATCTCTG & 5'-GCTGCTCTCCCAGTGCAAAG & 149 \\
\hline $1 \mathrm{c}$ & 5'-CCAGACTCTCCTCTGAACTC & 5'-GAAGAAGAGGTTCCATCTGA & 145 \\
\hline 2 & 5'-TGCAGATGCCTGGTGACAGC & 5'-CACAGCTGCTTCTGGATGAG & 290 \\
\hline 3 & 5'-TAATATCCGGCTCAGTCACC & 5'-CTGAGATCCTGCATGCCTTG & 295 \\
\hline 4 & 5'-TAGCTTGGCTTGAGGCCGTG & 5'-TGAAGGCAGAGTTCCTCI'GG & 272 \\
\hline 5 & 5'-GCAGCCACGAGGCCTATCTC & 5'-GAGAAAGGCAGGCAGTGCTG & 195 \\
\hline 6 & 5'-CCAGCACTGCAGCTTCTGTG & 5'-GAGCCTCGGCAGTCTGGAAG & 176 \\
\hline 7 & 5'-AGTGCAGCTCTCGCTGACAG & 5'-CATCTGCCGCTGCACCAGAG & 285 \\
\hline 8 & 5'-TGCCTGCTGATGTAATGGTC & 5'-TGAGACCAAGTCTGCAGTGC & 263 \\
\hline 9 & 5'-ACTGTCGGAGCGACACTCAG & 5'-CTTGGAGCTTGGGAACCGCA & 367 \\
\hline 10 & 5'-GTCGACTGCGTGCAGGGCGC & 5'-TGTGGCATCCTCCCTGCGCT & 263 \\
\hline
\end{tabular}

restriction analysis.

\section{RESULTS}

$36.6 \%$ of our study families (11 subjects of 30 patients), carried mutations in GCK gene (MODY2). All of these mutations have been reported previously. We identified 6 Mutations in 11 patients (Table 2). None of the mutations in GCK gene reported here were identified in 21 normoglycemic relatives and 50 normal chromosomes from unrelated healthy control subjects. In our last study, we had three families with clinical and genetic characteristics of MODY1 (26.6\%) [27]. According to this result and present data (determined 5 family with MODY 2); in 4 of 12 families (One third of population) no mutations were found in the GCK and HNF4 $\alpha$ genes. This finding shows that the majority of MODY mutations in Iranian population are MODY2 and that other MODY genes such as MODYX could be responsible for autosomal dominant transmission of diabetes mellitus.

Close to $40 \%$ of the reported mutations in the GCK gene are present in exon7 [28]. In our results, the Thr228 Ala mutation was found in two families not known to be related, who were subsequently considered to be members of the same pedigree.

This mutation has the most frequency rather than other mutations $(36.3 \%)$. All the other mutations were only detected in one family. Frequency of GCK mutations in Iranian patients is shown in Table $\mathbf{3}$.

At the time of investigation, the mean age of our patients was 31 years (range 14 to 51 years) and the mean age of apparent onset (first recognition of hyperglycemia) was 19 years (range 11 to 25 years). So, similar to other populations, the phenotype expression of MODY2 usu- ally appears earlier in life. None of the diabetic individuals are obese; the mean of Body Mass Index (BMI) in our patients was $20.7 \mathrm{~kg} / \mathrm{m}^{2}$ (range 17.4 to $23.8 \mathrm{~kg} / \mathrm{m}^{2}$ ). The mean measured fasting glucose level and $\mathrm{HbA}_{1} \mathrm{C}$ in these patients was $7.4 \mathrm{mmol} / \mathrm{lit}$ and $6.7 \%$ respectively. The majority of our patients showed mild/moderate hyperglycemia, confirming the previously reported observation that GCK mutations are associated with milder non progressive hyperglycemia as compared with other MODY related genes. According to the last studies, overt diabetes is rare in MODY2, but in our investigation, one patient presented overt diabetes. She had a history of Gestational Diabetes Mellitus (GDM). This patient is well controlled with oral hypoglycemic agents after her pregnancy and the rest of patients are controlled with low dose of oral hypoglycemic agents, diet and physical exercise. In agreement with previous observations [29], no evidence of chronic complications of diabetes was found in affected members of these families. Clinical features of subjects with GCK mutations are summarized in Table 4 .

\section{DISCUSSION}

Molecular defects in six different genes have been identified in MODY patients [30]. All of these genes encode proteins involved in the glucose homeostasis of the pancreatic beta cell. The glucokinase gene (GCK/ MODY2) encodes an enzyme of the glycolytic pathway, which can modulate insulin secretion in response to glycemic variations and the other five genes encode nuclear proteins that control the appropriate expression of beta cell genes [31-33]. Heterozygous mutations in these genes may result in different clinical presentations. Iden- 
Table 2. Characteristics of Iranian families with GCK mutations.

\begin{tabular}{|c|c|c|c|c|c|}
\hline Family number & Affected members/total members & Number of affected member & Location & Codon & Nucleotide change (variant) \\
\hline \multirow{3}{*}{1} & \multirow{3}{*}{$3 / 4$} & $\neq 1$ & Exon 7 & 261 & $\mathrm{G} \rightarrow \mathrm{A}(\mathrm{Gly} \rightarrow \mathrm{Arg})$ \\
\hline & & $\neq 2$ & Exon 7 & 261 & $\mathrm{G} \rightarrow \mathrm{A}(\mathrm{Gly} \rightarrow \mathrm{Arg})$ \\
\hline & & $\neq 3$ & Exon 7 & 261 & $\mathrm{G} \rightarrow \mathrm{A}(\mathrm{Gly} \rightarrow \mathrm{Arg})$ \\
\hline \multirow[b]{2}{*}{2} & \multirow{2}{*}{$2 / 7$} & $\neq 1$ & - & - & - \\
\hline & & $\neq 2$ & Exon 6 & 221 & $\mathrm{G} \rightarrow \mathrm{A}(\mathrm{Glu} \rightarrow \mathrm{Lys})$ \\
\hline 3 & $1 / 1$ & $\neq 1$ & Exon 6 & 226 & $\mathrm{G} \rightarrow \mathrm{A}(\mathrm{Val} \rightarrow \mathrm{Met})$ \\
\hline \multirow{4}{*}{4} & \multirow{4}{*}{$4 / 5$} & $\neq 1$ & Exon 7 & 228 & $\mathrm{C} \rightarrow \mathrm{T}(\mathrm{Thr} \rightarrow$ Ala $)$ \\
\hline & & $\neq 2$ & Exon 7 & 228 & $\mathrm{C} \rightarrow \mathrm{T}(\mathrm{Thr} \rightarrow$ Ala $)$ \\
\hline & & $\neq 3$ & Exon 7 & 228 & $\mathrm{C} \rightarrow \mathrm{T}(\mathrm{Thr} \rightarrow \operatorname{Arg})$ \\
\hline & & $\neq 4$ & Exon 7 & 228 & $\mathrm{C} \rightarrow \mathrm{T}(\mathrm{Thr} \rightarrow \mathrm{Met})$ \\
\hline \multirow{2}{*}{5} & \multirow{2}{*}{$2 / 2$} & $\neq 1$ & Exon 7 & 228 & $\mathrm{C} \rightarrow \mathrm{T}(\mathrm{Thr} \rightarrow$ Ala $)$ \\
\hline & & $\neq 2$ & Exon 7 & 228 & $\mathrm{C} \rightarrow \mathrm{T}(\mathrm{Thr} \rightarrow$ Ala $)$ \\
\hline
\end{tabular}

Table 3. Frequency of different mutations in GCK gene in Iranian subjects with MODY.

\begin{tabular}{cccc}
\hline Location & Codon & Nucleotide change & Frequency \\
\hline Exon 6 & 221 & $\mathrm{G} \rightarrow \mathrm{A}(\mathrm{Glu} \rightarrow \mathrm{Lys})$ & $27.2 \%(3 / 11)$ \\
Exon 6 & 226 & $\mathrm{G} \rightarrow \mathrm{A}(\mathrm{Val} \rightarrow \mathrm{Met})$ & $9 \%(1 / 11)$ \\
Exon 7 & 261 & $\mathrm{G} \rightarrow \mathrm{A}(\mathrm{Gly} \rightarrow \mathrm{Arg})$ & $9 \%(1 / 11)$ \\
Exon 7 & 228 & $\mathrm{C} \rightarrow \mathrm{T}(\mathrm{Thr} \rightarrow \mathrm{Ala})$ & $36.3 \%(4 / 11)$ \\
Exon 7 & 228 & $\mathrm{C} \rightarrow \mathrm{T}(\mathrm{Thr} \rightarrow \mathrm{Arg})$ & $9 \%(1 / 11)$ \\
Exon 7 & 228 & $\mathrm{C} \rightarrow \mathrm{T}(\mathrm{Thr} \rightarrow \mathrm{Met})$ & $9 \%(1 / 11)$ \\
\hline
\end{tabular}

Table 4. Clinical characteristics of subjects with mutations in GCK gene.

\begin{tabular}{|c|c|c|c|c|c|c|c|}
\hline Family & $\operatorname{Sex}(F / M)$ & Age & Age at diagnosis & $\operatorname{BMI}\left(\mathrm{kg} / \mathrm{m}^{2}\right)$ & FBG mmol/lit & $\mathrm{HbA}_{1} \mathrm{C}(\%)$ & Therapy \\
\hline \multirow{3}{*}{1} & M & 19 & 16 & 22.1 & 6.8 & 6.3 & OHA \\
\hline & $\mathrm{F}$ & 27 & 19 & 21.1 & 7.1 & 6.3 & Diet and exercise \\
\hline & M & 14 & 11 & 18.4 & 6.5 & 6.5 & OHA \\
\hline \multirow{2}{*}{2} & $\mathrm{~F}$ & 29 & 23 & 23.2 & 13.7 & 8.7 & Insulin \\
\hline & F & 37 & 14 & 18.6 & 7.1 & 7.3 & Diet \\
\hline 3 & $\mathrm{~F}$ & 24 & 17 & 19.3 & 6.3 & 5.5 & Diet and exercise \\
\hline \multirow{4}{*}{4} & $\mathrm{~F}$ & 51 & 25 & 20.9 & 6.1 & 6.4 & Diet and exercise \\
\hline & M & 48 & 25 & 17.4 & 6.9 & 6.7 & Diet and exercise \\
\hline & M & 28 & 18 & 22.6 & 8.2 & 7.1 & OHA \\
\hline & $\mathrm{F}$ & 23 & 21 & 23.8 & 6.0 & 6.2 & Diet \\
\hline \multirow{2}{*}{5} & $\mathrm{~F}$ & 23 & 20 & 21.7 & 7.7 & 6.9 & OHA \\
\hline & F & 49 & 19 & 19.7 & 6.3 & 7.0 & OHA \\
\hline
\end{tabular}

Body mass index (BMI) was calculated as weight/height ${ }^{2}$. FBG: Fasting Blood Glucose. OHA: Oral Hypoglycemic Agent. 
tification of MODY genes currently allows investigation of the specific defects present in each family and definition of the respective genotype phenotype correlations [2].

More than 130 different GCK/MODY2 mutations have been identified [2]. In France, GCK mutations are the most common cause of MODY, with more than $60 \%$ of studied population carrying mutations in this gene [12, 18,21]. GCK defects are also the first cause of MODY among Italian and Spanish patients [29,34]. However, studies in the United Kingdom [35] and Germany [5] found GCK mutations in only $11 \%$ and $8 \%$ of the series, respectively. It has shown that mutations in GCK gene are not found in Mexican families with clinically diagnosis of MODY [28] and GCK mutations are relatively rare in Denmark [13]. This is in line with previous reports from Northern Europe [5,7,18,36] but conflicts with several, but not all, reports from Southern and Central Europe where mutations in GCK are the most prevalent cause of MODY [9,10,36,37].

We initiated a study of genetic epidemiology of MODY in Iranian populations, as no data on the relative prevalence of the different MODY subtypes and on the spectrum of mutations in MODY genes have been published from other countries [27]. In our first study on patients with clinical features of MODY, we distinguished three families with clinical and genetic characteristics of MODY1 (26.6\%) [27]. According to previous reports, MODY4-6 mutations are not likely to be responsible for diabetes in a substantial proportion of affected families, so we have not tested them [2]. In this project, we have screened for mutations in GCK gene in 12 Iranian families (30 patients and their 21 family members) fulfilling MODY criteria. We have found 6 mutations in glucokinase gene in 11 of our 30 MODY patients (5 Families), that they were not seen on screening 21 family members and the control subjects. This is implying that these mutations are the cause of the diabetes in the $36.6 \%$ of the patients that we studied.

While each genetic entity may be associated with distinct phenotypic features, the diagnosis cannot be always made on clinical grounds alone, and the associated clinical findings emphasize that the clinical distinction between the type 1 diabetes and MODY may be sometimes difficult. While almost all patients with type 1 diabetes are insulin dependent within 2 years of diagnosis, many MODY patients usually achieve good glycemic control without insulin throughout life.

Thus, knowledge of the genetic cause of MODY has significant impact on clinical management and therapeutic decision, allows prediction of the clinical course, and may offer the possibility of identifying family members at future risk. Also, the identification of a GCK mutation is important as it represents "good news". The stable, mild and subclinical hyperglycemia rarely requires phar- macological treatment and diabetic complications are unlikely. Our patients had mild elevations in fasting plasma glucose too, and no signs of diabetic complications were found in any of our subjects with a GCK mutation. All patients had an HbA1c level within the normal range indicating good glycemic control during the recent weeks.

She was the only patient among our families with GCK mutation ( $\neq 1$ of family 2 ) who had history of gestational diabetes and prescription of insulin during her life.

She had no mutation in GCK gene, whereas her sister has clinical and genetic characteristics of MODY2. So, MODY 2 should not be excluded in patients with more marked hyperglycemia, and that genetic screening of the GCK gene is a helpful strategy in all family members of MODY patients; because, we should think on T1D in the relatives of MODY patients.

In conclusion, the findings of this study indicate that mutations in GCK/MODY2 gene are a very common cause of MODY in IRAN.

Our experience also consistent with the idea that the availability of molecular diagnostic methods in a clinical setting not only may help to confirm a diagnosis of MODY, but also may be used for pre symptomatic diagnosis.

\section{CONCLUSIONS}

According to previous studies, additional unknown MODY genes (MODYX) may cause MODY and approximately $15 \%$ - $20 \%$ of families fitting MODY criteria do not have mutations in any of the known genes [38]; in the future we will study more on genetic characteristics of MODY patients.

The last point is, if mutations in GCK can contribute to the development of NIDDM, then acquired changes resulting in decreased levels of GCK may have the same effect. So, GCK may be a target for therapeutic intervention.

\section{ACKNOWLEDGEMENTS}

This research has been supported by Mashhad University of Medical Sciences Research Grant Committee. The work presented here was begun in the laboratory of Bu-Ali Research Center (Immunogenetics department) under the above grant. We foremost thank patients and their family members for their time and cooperation. We also thank all physicians and clinical departments referring patients to Ghaem Hospital for MODY examination. We are indebted to Mr. Behjati and $\mathrm{Mr}$. Shariati for their technical assistance.

\section{REFERENCES}

[1] Fajans, S.S., Bell, G.I., Bowden, D.W., Halter, J.B. and Polonsky, K.S. (1994) Maturity onset diabetes of the 
young. Life Sciences, 55, 413-422. http://dx.doi.org/10.1016/0024-3205(94)90052-3

[2] Fajans, S.S., Bell, G.I. and Polonsky, K.S. (2001) Molecular mechanisms and clinical pathophysiology of maturity onset diabetes of the young. New England Journal of Medicine, 345, 971-980.

http://dx.doi.org/10.1056/NEJMra002168

[3] Guazzarotti, L., Fumelli, P., Testa, I., Pecora, R., Panicari, F., Bellanne-Chantelot, C. and Bartolotta, E. (2001) Diagnosis of MODY in the offspring of parents with insulin dependent and non insulin dependent diabetes mellitus. Journal of Pediatric Endocrinology and Metabolism, 14, 611-617. http://dx.doi.org/10.1515/JPEM.2001.14.S1.611

[4] Ehtisham, S., Hattersley, A.T., Dunger, D.B. and Barrett, T.G. (2004) British Society for Paediatric Endocrinology and Diabetes Clinical Trials Group. First UK survey of paediatric type 2 diabetes and MODY. Archives of Disease in Childhood, 89, 526-529.

http://dx.doi.org/10.1136/adc.2003.027821

[5] Lindner, T.H., Cockburn, B.N. and Bell, G.I. (1999) Molecular genetics of MODY in Germany. Diabetologia, 42, 121-123. http://dx.doi.org/10.1007/s001250051128

[6] Costa, A., Bescos, M., Velho, G., Chevre, J., Vidal, J., Sesmilo, G., Bellanne Chantelot, C., Froguel, P., Casamitjana, R., Rivera-Fillat, F., Gomis, R. and Conget, I. (2000) Genetic and clinical characterisation of maturity onset diabetes of the young in Spanish families. European Journal of Endocrinology, 142, 380-386. http://dx.doi.org/10.1530/eje.0.1420380

[7] Frayling, T.M., Evans, J.C., Bulman, M.P., Pearson, E., Allen, L., Owen, K., Bingham, C., Hannemann, M., Shepherd, M., Ellard, S. and Hattersley, A.T. (2001) Cell genes and diabetes: Molecular and clinical characterization of mutations in transcription factors. Diabetes, 50, S94-S100. http://dx.doi.org/10.2337/diabetes.50.2007.S94

[8] Gragnoli, C. (2001) Early onset type II diabetes mellitus in Italian families due to mutations in the genes encoding hepatic nuclear factor $1 \alpha$ and glucokinase. Diabetologia, 44, 1326-1329. http://dx.doi.org/10.1007/s001250100644

[9] Barrio, R., Bellanne-Chantelot, C., Moreno, J.C., Morel, V., Calle, H., Alonso, M. and Mustieles, C. (2002) Nine novel mutations in maturity onset diabetes of the young (MODY) candidate genes in 22 Spanish families. Journal of Clinical Endocrinology \& Metabolism, 87, 2532-2539. http://dx.doi.org/10.1210/jc.87.6.2532

[10] Pruhova, S., Ek, J., Lebl, J., Sumnik, Z., Saudek, F., Andel, M., Pedersen, O. and Hansen, T. (2003) Genetic epidemiology of MODY in the Czech Republic: New mutations in the MODY genes HNF $4 \alpha$, GCK and HNF $1 \alpha$. Diabetologia, 46, 291-295.

[11] Pearson, E.R., Pruhova, S., Tack, C., Johansen, A., Castleden, H., Wierzbecki, A., Clark, P.M., Pedersen, O., Lebl, J., Ellard, S., Hansen, T. and Hattersley, A.T. (2005) Molecular genetics and phenotypic characteristics of MODY caused by hepatocyte nuclear factor $4 \alpha$ mutations in a large European collection. Diabetologia, 48, 878885. http://dx.doi.org/10.1007/s00125-005-1738-y

[12] Hattersley, A.T. (1998) Maturity onset diabetes of the young: Clinical heterogeneity explained by genetic heterogeneity. Diabetic Medicine, 15, 15-24.

http://dx.doi.org/10.1002/(SICI)1096-9136(199801)15:1< 15::AID-DIA562>3.0.CO;2-M

[13] Johansen, A., J. Ek, Mortensen, H.B., Pedersen, O. and Hansen, T. (2005) Half of clinically defined maturity onset diabetes of the young patients in Denmark do not have mutations in HNF $4 \alpha$, GCK and TCF1. The Journal of Clinical Endocrinology and Metabolism, 90, 4607-4614. http://dx.doi.org/10.1210/jc.2005-0196

[14] Stoffel, M., Froguel, P., Takeda, J., Zouali, H., Vionnet, N., Nishi, S., Weber, I.T., Harrison, R.W., Pilkis, S.J., Lesage, S., Vaxillaire, M., Velho, G., Sun, F., Iris, F., Passa, P., Cohen, D. and Bell, G.I. (1992) Human glucokinase gene: Isolation, characterization, and identification of two missense mutations linked to early onset non insulindependent (type 2) diabetes mellitus. Proceedings of the National Academy of Sciences of the United States of America, 89, 7698-7702.

http://dx.doi.org/10.1073/pnas.89.16.7698

[15] Shimada, F, Makino, H., Hashimoto, N., Taira, M., Seino, S., Bell, G.I., Kanatsuka, A. and Yoshida, S. (1993) Type 2 (non insulin dependent) diabetes mellitus associated with a mutation of the glucokinase gene in a Japanese family. Diabetologia, 36, 433-437. http://dx.doi.org/10.1007/BF00402280

[16] Matschinsky, F., Liang, Y., Kesavan, P., Wang, L., Froguel, P., Velho, G., Cohen, D., Permutt, M.A., Tanizawa, Y., Jetton, T.L., Niswender, K. and Magnuson, M.A. (1993) Glucokinase as pancreatic beta cell glucose sensor and diabetes gene. Journal of Clinical Investigation, 92, 2092-2098. http://dx.doi.org/10.1172/JCI116809

[17] Stoffel, M., Bell, K.L., Blackburn, C.L., Powell, K.L., Seo, T.S., Takeda, J., Vionnet, N., Xiang, K.S., Gidh-Jain, M., Pilkis, S.J., Ober, C. and Bell, G.I. (1993) Identification of glucokinase mutations in subjects with gestational diabetes mellitus. Diabetes, 42, 937-940. http://dx.doi.org/10.2337/diab.42.6.937

[18] Froguel, P., Zouali, H., Vionnet, N., Velho, G., Vaxillaire, M., Sun, F., Lesage, S., Stoffel, M., Takeda, J., Passa, P., Permutt, M.A., Beckmann, J.S., Bell, G.I. and Cohen, D. (1993) Familial hyperglycemia due to mutations in glucokinase: Definition of a subtype of diabetes mellitus. New England Journal of Medicine, 328, 697-702. http://dx.doi.org/10.1056/NEJM199303113281005

[19] Zouali, H., Vaxillaire, M., Lesage, S., Sun, F., Velho, G., Vionnet, N., Chiu, K., Passa, P., Permutt, A., Demenais, F., Cohen, D., Beckmann, J.S. and Froguel, P. (1993) Linkage analysis and molecular scanning of glucokinase gene in NIDDM families. Diabetes, 42, 1238-1245. http://dx.doi.org/10.2337/diab.42.9.1238

[20] Hager, J., Blanche, H., Sun, F., Vaxillaire, N.V., Poller, W., Cohen, D., Czernichow, P., Velho, G., Robert, J.J., Cohen, N. and Froguel, P. (1994) Six mutations in the glucokinase gene identified in MODY by using a nonradioactive sensitive screening technique. Diabetes, 43, 730733. http://dx.doi.org/10.2337/diab.43.5.730

[21] Velho, G., Blanche, H., Vaxillaire, M., Bellanne-Chantelot, C., Pardini, V.C., Timsit, J., Passa, P., Deschamps, I., Robert, J.J., Weber, I.T., Marotta, D., Pilkis, S.J., Lipkind, 
G.M., Bell, G.I. and Froguel, P. (1997) Identification of 14 new glucokinase mutations and description of the clinical profile of 42 MODY2 families. Diabetologia, 40, 217224. http://dx.doi.org/10.1007/s001250050666

[22] Velho, G., Froguel, P., Clement, K., Pueyo, M.E., Rakotoambinina, B., Zouali, H., Passa, P., Cohen, D. and Robert, J.J. (1992) Primary pancreatic beta cell secretory defect caused by mutations in glucokinase gene in kindreds of maturity onset diabetes of the young. Lancet, 340, 444-448. http://dx.doi.org/10.1016/0140-6736(92)91768-4

[23] Byrne, M.M., Sturis, J., Clement, K., Vionnet, N., Pueyo, M.E., Stoffel, M., Takeda, J., Passa, P., Cohen, D., Bell, G.I., Velho, G., Froguel, P. and Polonsky, K.S. (1994) Insulin secretory abnormalities in subjects with hyperglycemia due to glucokinase mutations. Journal of Clinical Investigation, 93, 1120-1130. http://dx.doi.org/10.1172/JCI117064

[24] Velho, G., Petersen, K.F., Perseghin, G., Hwang, J.H., Rothman, D.L., Pueyo, M.E., Cline, G.W., Froguel, P. and Shulman, G.I. (1996) Impaired hepatic glycogen synthesis in glucokinase deficient (MODY2) subjects. Journal of Clinical Investigation, 98, 1755-1761. http://dx.doi.org/10.1172/JCI118974

[25] Pearson, E.R., Velho, G., Clark, P., Stride, A., Shepherd, M., Frayling, T.M., Bulman, M.P., Ellard, S., Froguel, P. and Hattersley, A. (2001) $\beta$ cell genes and diabetes: Quantitative and qualitative differences in the pathophysiology of hepatic nuclear factor $1 \alpha$ and glucokinase mutations. Diabetes, 50, S101-S107.

http://dx.doi.org/10.2337/diabetes.50.2007.S101

[26] Rose, C.S., Ek, J., Urhammer, S.A., Glumer, C., BorchJohnsen, K., Jorgensen, T., Pedersen, O. and Hansen, T. (2005) A-30G $>$ A Polymorphism of the $\beta$ cell specific Glucokinase promoter associates with Hyperglycemia in the general population of whites. Diabetes, 54, 30263031. http://dx.doi.org/10.2337/diabetes.54.10.3026

[27] Taghavi, S.M., Fatemi, S.S., Rafatpanah, H., Ganjali, R., Tavakolafshari, J. and Valizadeh, N. (2009) Mutations in the coding regions of the hepatocyte nuclear factor 4 alpha in Iranian families with maturity onset diabetes of the young. Cardiovascular Diabetology, 8, 63. http://dx.doi.org/10.1186/1475-2840-8-63

[28] del Bosque-Plata, L., Garcia-Garcia, E., Ramirez-Jimenez, S., Cabello-Villegas, J., Riba, L., Gomez-Leon, A., VegaHernandez, G., Altamirano-Bustamante, N., Calzada-Leon, R., Robles-Valdes, C., Mendoza-Morfin, F., Curiel-Perez, O. and Tusie Luna, M.T. (1997) Analysis of the Glucokinase gene in Mexican families displaying early onset non insulin dependent diabetes mellitus including MODY families. American Journal of Medical Genetics, 72, 387-393.

http://dx.doi.org/10.1002/(SICI)1096-8628(19971112)72: 4<387::AID-AJMG3>3.0.CO;2-O

[29] Barrio, R., Bellanne Chantelot, C., Moreno, J.C., Morel, V., Calle, H., Alonso, M. and Mustieles, C. (2002) Nine novel mutations in Maturity Onset Diabetes of the Young (MODY) candidate genes in 22 Spanish families. The Journal of Clinical Endocrionology and Metabolism, 8,

\section{2-2539. http://dx.doi.org/10.1210/jc.87.6.2532}

[30] Doria, A. and Plengvidhya, N. (2000) Recent advances in the genetics of maturity onset diabetes of the young and others forms of autosomal dominant diabetes. Current Opinion in Endocrinology and Diabetes, 7, 203-210.

[31] Froguel, P.H., Vaxillaire, M., Sun, F., Velho, G., Zouali, H., Butel, M.O., Lesage, S., Vionnet, N., Clement, K., Fougerousse, F., Tanizawa, Y., Weissenbach, J., Beckmann, S., Lathrop, G.M., Passa, P.H., Permutt, M. and Cohen, D. (1992) The glucokinase locus on chromosome $7 \mathrm{p}$ closely linked to early onset non insulin dependent diabetes mellitus. Nature, 356, 162-164. http://dx.doi.org/10.1038/356162a0

[32] Matschinsky, F.M. (1990) Glucokinase as glucose sensor and metabolic signal generator in pancreatic $\beta$ cells and hepatocytes. Diabetes, 39, 647-652. http://dx.doi.org/10.2337/diab.39.6.647

[33] Postic, C., Shiota, M., Niswender, K.D., Jetton, T.L., Chen, Y., Moates, J.M., Shelton, K.D., Lindner, J., Cherrington, A.D. and Magnuson, M.A. (1999) Dual roles for glucokinase in glucose homeostasis as determined by liver and pancreatic $\beta$ cell specific gene knock out using Cre recombinase. Journal of Biological Chemistry, 274, 305-315. http://dx.doi.org/10.1074/jbc.274.1.305

[34] Massa, O., Meschi, F., Cuesta-Munoz, A., Caumo, A., Cerutti, F., Toni, S., Cherubini, V., Guazzarotti, L., Sulli, N., Matschinsky, F.M., Lorini, R., Iafusco, D. and Barbetti, F. (2001) High prevalence of glucokinase mutations in Italian children with MODY. Influence on glucose tolerance, first phase insulin response, insulin sensitivity and BMI. Diabetologia, 44, 898-905. http://dx.doi.org/10.1007/s001250100530

[35] Beards, F., Frayling, T., Bulman, M., Horikawa, Y., Allen, L., Appleton, M., Bell, G.I., Ellard, S. and Hattersley, A.T.M. (1998) Mutations in hepatocyte nuclear factor $4 \alpha$ are not a common cause of maturity onset diabetes of the young in the UK. Diabetes, 47, 1152-1154. http://dx.doi.org/10.2337/diabetes.47.7.1152

[36] Lehto, M. (1999) High frequency of mutations in MODY and mitochondrial genes in Scandinavian patients with familial early onset diabetes. Diabetologia, 42, 11311137. http://dx.doi.org/10.1007/s001250051281

[37] Froguel, P. (1998) Insulin promoter factor 1 gene is not a major cause of maturity onset diabetes of the young in French Caucasians. Diabetes, 47, 843-844. http://dx.doi.org/10.2337/diabetes.47.5.843

[38] Frayling, T.M., Lindgren, C.M., Chevre, J.C., Menzel, S., Wishart, M., Benmezroua, Y., Brown, A., Evans, J.C., Subba Rao, P., Dina, C., Lecoeur, C., Kanninen, T., Almgren, P., Bulman, M.P., Wang, Y., Mills, J., Wright-Pascoe, R., Mahtani, M.M., Prisco, F., Costa, A., Cognet, I., Hansen, T., Pedersen, O., Ellard, S., Tuomi, T., Groop, L.C., Froguel, P., Hattersley, A.T. and Vaxillaire, M. (2003) A genome wide scan in families with maturity onset diabetes of the young: Evidence further genetic heterogeneity. Diabetes, 52, 872-881. http://dx.doi.org/10.2337/diabetes.52.3.872 